\title{
WHISTLEBLOWING: THE DEVELOPMENT OF WHISTLEBLOWING LAWS IN THE UNITED STATES AND EUROPE (DE LEGE FERENDA REMARKS)
}

\begin{abstract}
Corruption, harassment in a workplace, practices contrary to the correct work process, and many others are irregularities that can arise in any enterprise. This is a problem that affects established democracies and free markets and post-communist countries that are transitioning to democracy and market economies. While the causes of irregularities vary, the tools often suggested tackling them include that do not necessarily encourage potential whistleblowers to report them, whether inside or outside the organization. This article discusses the role of whistleblowing as a whistleblowing tool. Describes the law and whistleblowing in a comparative context, focusing on the United States and the European Union. The article then concludes with recommendations for strengthening whistleblowing in Europe, where reporting irregularities is just beginning, and the level of protection differs between the Member States.
\end{abstract}

Słowa kluczowe: whistleblowing, sygnalista, Stany Zjednoczone, Unia Europejska

Keywords: whistleblowing, whistleblower, United States, European Union

ASJC: 3308, JEL: K31

\section{Introduction}

Fighting irregularities, whether in the public or private sector, is an inherent problem not only faced by well-established democratic economies but also post-communist countries transitioning to democracy and a market economy, but it is also a problem faced by countries in North America and Western Europe, including the European Union Member States. ${ }^{1}$ The problem of irregularities cannot be eliminated, but can be effectively reduced. Therefore, public and private sector employers try to implement some

1 https://www.consilium.europa.eu/en/press/press-releases/2019/10/07/better-protection-of-whistle-blowers-new-eu-wide-rules-to-kick-in-in-2021/ (access: 27 October 2020). 
mechanisms and solutions to solve this problem through greater transparency and improved management (Near et al. 2009, pp. 379-396). Some countries have introduced high confidentiality and financial rewards incentives for whistleblowers. ${ }^{2}$ Such regulatory strategies are one side of securing the interests of whistleblowers, who often have moral dilemmas in reporting irregularities (Chen, Lai 2014, pp. 327-342). However, the essential tools to improve whistleblowers' status are the legal provisions governing whistleblowing and the scope of whistleblower protection. Reporting irregularities is not a solution to all problems in the ethical and legal management of the institution, but it can be a remedial element of the organization.

This article discusses the role of whistleblowing as a tool to tackle public and private sector irregularities. The article analyzes the methodological of whistleblowing provisions in a comparative context, focusing on the United States and the European Union. The article then concludes with de lege ferenda conclusions on how irregularities reporting, especially in the European Union, can be enhanced.

\section{Whistleblowing: Definition.}

Before analyzing whistleblower protection provisions, it will be justified to present a definition of whistleblowing, which has undergone a massive transformation over the years. The term whistleblowing is becoming commonplace. This section summarizes how the term whistleblowing has developed from its inception to the present day. To this end, it will analyze how the term has been - and is-understood and defined in science.

Albert Otto Hirschman in 1970 (pp. 1-21) made a distinction between various ways of expressing opposition to the situation in a given organization. One way to react is for a member to leave the organization or move to a competitor. The second way is to be much more influential because its task is to agitate against the first organization's irregularities and try to exert pressure and, consequently, change. It should be noted that this definition draws attention to two different goods, i.e., public good and loyalty to the employer. The person who uses the first method of objection is more loyal to the employer than the person who decides to move to a competing company. At the same time, for Hirschman, loyalty is seen as a function of delaying the exit and allowing the employee to play the right role.

According to Ralph Nader's definition (Nader, Petkas, Blackwell 1972, p. 7) from 1971, an employee's reaction to irregularities is the awareness that the public interest outweighs the organization's interest and thus signal that the organization is engaged in corrupt, illegal, or harmful activities.

2 E.g., United States, Canada; Ontario Securities Commission (OSC), https://www.osc.gov.on.ca/ en/NewsEvents_nr_20180629_osc-whistleblower-program-contributing-to-a-stronger-culture-of-compliance.htm (access: 27 October 2020). 
Janet Near and Marcia Miceli (Near, Miceli 1985, pp. 1-16) were among the first researchers to define the term "whistleblowing" and describe it as behavior as "disclosure by members of an organization (former or current) of illegal, immoral or illegal practices to persons or organizations that may be able to take action in this regard." Their definition is precise and makes it clear that the employee, as a rule, by informing, goes beyond his workplace and reports these irregularities to third parties or appropriate institutions. These persons or institutions must be able to react, i.e., they must be able to take action while ensuring the whistleblower's protection. There is no doubt that in labor law, we still deal with strong axiology of protection of the "weaker" against the "stronger," which is strongly present in labor law, in the name of equalizing the actual position. In this case, it is justified to conclude that the "employee" or "non-employee" position with the employing entity is weaker concerning the employer. An employee's decision to inform about irregularities is influenced by many variables: the nature of the offense, the situation at the workplace, potential threats, and fear of retaliation (Liszcz 2005, p. 22; Sobczyk 2014, p. 1). Many researchers have supported the appeal to informing via external channels. For example, Dan Farrell and James Petersen (Farrel, Petersen 1982, pp. 402-412) saw whistleblowing only as a process of disclosing information to parties outside the organization. According to Granville King III (1999, pp. 315-326), the whistleblower may also inform entities not usually dealing with whistleblower protection, e.g., the media.

Besides, John Boatright (2000) gives a similar definition that focuses on external reporting of public interest. In his opinion, whistleblowing is:

voluntary disclosure of non-public information about illegal and immoral conduct in an organization or behavior in an organization that is contrary to the public interest by a member or former member of an organization without using standard channels of communication with the relevant organization (Jubb 1999, pp. 77-94).

It points out that whistleblowing is an "optional act of disclosure" which is "made by a person who has or has had access to an organization's data or information." At the same time, what is interesting, it distinguishes between signaling irregularities and informing about noticed violations through traditional channels of information in the workplace. He continues by confirming that whistleblowing is different from certain types of reporting as whistleblowing is a type of accusation against his employer as disclosure is an allegation of misconduct, incompetence, or fraud.

Michael Rehg and James R. Van Scotter (Near et al. 2004, pp. 219-242) state that the definition created by Peter B. Jubb allows for empirical determination of the differences between the types of whistleblowers, assuming that the standard informing of the employee to his employer about the observed irregularity is whistleblowing. The authors divided whistleblowing into the so-called external and internal. Roberta Ann Jonson describes whistleblowing as a form of objection that has four features: Disclosing information to the public is an individual act outside the whistleblower's organization, 
i.e., notifying an external person or institution that makes it public and forms part of the public register.

1. The information disclosed relates to serious misconduct in this organization.

2. The disclosing person is a member of this organization.

In short, an informant is someone who exposes misconduct in an organization. Johnson's definition does not include, for example, issues related to the so-called informing inside the organization (Johnson 2003, p. 3).

For this article, I assume that a whistleblower is a person who discloses information or activities of a given organization outside of it that are reasonably illegal, unethical, or otherwise inappropriate, regardless of whether the disclosure concerns the public or private sector (Kobroń 2013, p. 296; 2015, pp. 81-92; Kobroń-Gąsiorowska 2018, pp. 129-142). It takes the position that whistleblowers are most often employees. However, anyone who discloses irregularities in the workplace or a public institution can be a whistleblower (Kobroń-Gąsiorowska 2019, pp. 333-343). Given the above, notification of irregularities is a crucial mechanism in fighting fairness and the public interest. Its role as a reporting mechanism for misconduct, fraud, and other forms of illegal or unethical behavior allows the public to be aware of violations and violations that would otherwise remain hidden. This applies in particular to democratic countries where accountability and transparency, reinforced by reporting irregularities, are the fundamental values supporting the functioning of state apparatuses (Wolfe et al. 2014).

Accordingly, protecting the whistleblower from retaliation, disproportionate penalties, unfair treatment, and other forms of retaliation is essential as it enables employees to use appropriate channels to speak out against abuse. Consequently, it is necessary to ask which form of reporting will be a preferential form-external or internal-because employees who disclose internal or external information are exposed to retaliation, which may take the form of mobbing / harassment (I PR 16/75 of 3 March 1975 of the Supreme Court) or infringement of personal rights of a whistleblower-an employee (II UKN 620/00 of 15 November 2001 of the Supreme Court).

\section{United States: Legal framework and cultural context in whistleblower protection}

There can be no hesitancy that the United States is possibly a pioneer with whistleblowing laws. According to Johnson, the United States is the leading exporter of whistleblowing regulations that directly affect international agencies such as the World Bank, the Organization for Economic Co-operation and Development (OECD) and the Organization of American States (Johnson 2003, p. 3), but also recently European Union law. According to Simon Wolfe, the United States has the most extensive and best-enforced whistleblower protection system globally (Wolfe et al. 2014). It is hard to disagree with that. 
Many different US federal laws prohibit private-sector employers from retaliating against whistleblowers. For example, The False Claims Act (FCA) is the first US whistleblower law and one of the oldest whistleblower laws in the United States, then the Occupational Safety and Health Act of 1970 protects those who reported irregularities in the field of safety and health at work. In turn, the Criminal Fraud Accountability Act 2002 (Sarbanes-Oxley), extended by the Wall Street Reform and Consumer Protection Act 2010 (Dodd-Frank), protects the law on securities and whistleblowers who disclose irregularities in this respect. Most of these rights are handled by the Department of Labor (DOL) or the Occupational Safety and Health Agency (OSHA). Federal laws apply to anyone who reports government fraud or violations of federal anti-discrimination laws, federal laws that are specifically applicable to the protection of the public sector of employees and subcontractors (Omzigt 2009). Besides that, in many cases, in the United States, whistleblowers who disclose information about corruption, fraud, and abuse within their organizations are known to the public (Lacayo, Ripley 2002, pp. 32-33). While there are many whistleblowers in the United States, some publicly praised, reporting whistleblowing is not an easy process. For many whistleblowers, this has had dire consequences in their careers and personal lives. Some organizations make reporting on irregularities very difficult (Near, Miceli 1992, p. 187). Despite this fact, the United States remains a pioneer in the provision of information rules.

Because it would be unachievable to analyze all the whistleblowing laws in the United States, this article will review the most important laws relating to whistleblower protections in the public and private sectors. The provisions on whistleblowing should be understood as relating to three different types of corruption. The first is government corruption, government fraud in which government officials commit fraud through resource misuse, bribery, and political favoritism. The second type of law takes place in the private sector or among non-governmental organizations (NGOs). Among these regulations, we can find those that legalize or impose conditions under which irregularities reporting should occur. Still, others encourage whistleblowing or otherwise provide compensation or legal protections against retaliation for those who report whistleblowing.

\section{The False Claims Act: ${ }^{3}$ Government sector}

The first laws were regulating whistleblowing in the United States date back to the Civil War of 1863 the False Claims Amendment Act (FCA). In one of the first judgments, the court declared that [The False Claims Act]:

is intended to protect the treasury against the hungry and unscrupulous host that encompasses it on every side, and should be construed accordingly. It was passed upon the theory . . that one

3 False Claims Amendments Act (1986). Pub. L. No. 99-562, 100 Stat. 3153 (codified as amended at 31 U.S.C. $\$ \$ 3729-3733$ (1994), https://www.justice.gov/jmd/false-claims-amendments-act-1986pl-99-562 (access: 27 October 2020). 
of the least expensive and most effective means of preventing frauds on the treasury is to make the perpetrators of them liable to actions by private persons acting ... under the strong stimulus of personal ill will or the hope of gain. Prosecutions conducted by such means compare with the ordinary methods as the enterprising privateer does to the slow-going public vessel (United States v. Griswold, 24 F. 361, 366, 1885).

The FCA's purpose was to encourage citizens to assist the federal police in rampant military fraud during the Civil War. However, this law was mostly disused until 1986, when the US Congress modernized its procedures and approved significant amendments. The FCA has changed over the years due to criticism (United States ex rel. Marcus v. Hess, 317 U.S. 537, 541-42, 1943) of qui tam reward provision, ${ }^{4}$ which did not fulfill their role as compensation for reported irregularities. In 1943, an amendment to the law prohibited the lodging of complaints based on information already in the government's possession. This change was the periodic filing of complaints during World War II about which the government was already informed.

Above mentioned the most significant amendment to the 1986 Act disbarred any qui tam cases that had been disclosed either by the media or in criminal, civil, or administrative proceedings before a court (Calvert 1998, pp. 435-461). Initially, the qui tam reward provision was aimed at private-sector employees. However, in 1992 Congress unsuccessfully analyzed the problem of whether government officials who, by their functions, are required to report irregularities, should receive additional rewards for perhaps merely performing their work. The literature indicates that the 1986 amendments were enacted to promote whistleblowers and protect their financial participation qui tam activities and control the government from unjustified dismissal of lawsuits. Overall, nonetheless, the FCA encouraged many people to report fraud (False Claims Amendments Act of 1986, Pub. L. No. 99-562, 100 Stat. 3153, codified as amended at 31 U.S.C. $\$ \$ 3729-33)$. Since the last major amendments to the FCA in 1986 through and including fiscal year 2008, a total of 10,063 cases were filed under the civil FCA. ${ }^{5}$ Nowadays, critics of the FCA say financial rewards are a significant burden on many companies - and those that do it often do not want to risk more (Kobron 2013, pp. 296-302). There are, however, supporters of financial rewards for whistleblowers who argue that a strong monetary incentive to report misconduct motivates employees to disclose, to which they have the best access (Dyck, Morse, Zingales 2010). Government statistics also confirm this state of operations and the effectiveness of the act. ${ }^{6}$

4 The term qui tam is derived from a Latin phrase, qui tam pro domino rege quam pro se ipso, or "who pursues this action on our Lord the King's behalf as well as his own" (Vermont Agency of Natural Res. v. United States ex rel. Stevens, 529 U.S. 765, 769 n. 1, 2000).

5 https://www.crowell.com/documents/New-False-Claims-Act-Amendments-And-Their-ImpactOn-Health-Care-Fraud-Enforcement.pdf (access: 27 October 2020).

${ }^{6} \mathrm{https} / / /$ www.justice.gov/opa/pr/justice-department-recovers-over-3-billion-false-claims-act-casesfiscal-year-2019 (access: 27 October 2020). "In addition to combating health care fraud, the False Claims Act serves as the government' s primary civil tool to redress false claims for federal funds and property involving a multitude of other government operations and functions. The Act helps to protect our 


\section{Sarbanes Oxley and Dodd-Frank Act: Private sector ${ }^{7}$}

In the United States, most workers who observe workplace wrongdoing do not make any reports of irregularities. The first reason is that disclosure is not going to change anything. The second reason is fear of retaliation from an employer or other colleagues. In a country that is a pioneer in reporting misconduct, many consider a whistleblower is a person who chooses to inform misconduct outside the organization, as most employees believe that raising concerns in their workplace will solve the problem. They usually do not anticipate that their executives will see them as the main problem rather than the obstacles they report (Alford 2001).

The Sarbanes Oxley Act of 2002 (SOX) (Vaughn 2005) was enacted on 30 July 2002, in response to Enron and WorldCom's collapse, which caused disturbances in the US capital markets after detecting multiple accounting scandals. The Act aimed to increase the credibility and transparency of financial reporting, improving the management system by strengthening directors' role, and improving internal control practices and procedure (Bhagat, Bolton 2009). The SOX Act has adopted some rules to address these problems. The focal point of the Act is sections 302 and 402. The first deals with the company's financial reporting. The Act requires the $\mathrm{CEO}$ and $\mathrm{CFO}$ to personally confirm the financial statements' completeness and truthfulness and take personal responsibility for all internal controls and for the last 90 days. In turn, section 402 sets out further requirements for monitoring and maintaining internal control related to the company's accounting and finances. It obliges companies to audit these controls annually by an external company. This audit assesses all internal controls' effectiveness and communicates its findings directly to the Securities and Exchange Commission (Moberly 2012, pp. 1-54). However, one of SOX's new features was the creation of new rules for the whistleblowing procedure. SOX contains provisions that support and, in some cases, motivate whistleblowers. US doctrine indicates that SOX was the first law to introduce section 301 provisions to protect whistleblowers-employees of publicly traded companies who faced many different forms of retaliation for reporting fraud. The provision covered all industries.

According to section 301, a whistleblower must only demonstrate that retaliation reporting contributed to the disciplinary action and, consequently, the dismissal's direct reason. In this case, the burden of proof rests with the employer, who has to prove that the irregularity reporting was not the reason for the termination of the employment contract with the employee (Welch v. Cardinal Bankshares Corporation, Civil Action No. 7:05CV00546). Finally, section SOX 301 contains other provisions that place an obligation on companies to facilitate employee filing, even anonymously, of complaints

military and first responders by ensuring that government contractors provide equipment that is safe, effective, and cost efficient; to protect American businesses and workers by promoting compliance with customs laws, trade agreements, visa requirements, and small business protections; and to protect other critical government programs ranging from the provision of disaster relief funds to farming subsidies."

Sarbanes-Oxley Act (2002). Pub. L. 107-204, 116 Stat. 745. 
about suspected fraud. Over the years, Congress strengthened and based whistleblowing rules in several more bills. In 2009, The American Recovery and Reinvestment Act 2009 was passed. ${ }^{8}$ Section 1553 of the US Act extended "whistleblower protection" to employees who reasonably believe they are being retaliated for reporting the misapplication by private sector employers of federal funds received during the US financial crisis. The extension of the scope of whistleblower protections to the private sector in the Stimulus Act was also due to the Supreme Court's conclusions in the case of Garcetti v. Ceballos in 2006. ${ }^{9}$ According to the Supreme Court's conclusions, a public official may exercise the protected freedom of speech only during a private speech, and not in the performance of official duties. The employer's interest in limited statements made during the performance of employee duties. The judgment met with general public critique for being the first to restrict the strengthening of whistleblower protections in the U.S. (Kohn 2006). Then, in the Dodd-Frank Act of $2010^{10}$ (North, Buckley 2012, pp. 479-522), which was adopted in response to the financial meltdown and scandals that led to the economic crisis of 2008 (North, Buckley 2012, p. 241). The Dodd-Frank Act allows financial rewards to be granted to whistleblowers who provide information on violations of securities rules by companies required to report to the Securities and Exchange Commission. If an employer retaliates against a whistleblower for reporting wrongdoing, the employee has the right to sue him and receive twice the amount of arrears, reinstatement, and reimbursement of legal costs. The Dodd-Frank Act also requires whistleblowers' identities to be kept confidential. ${ }^{11}$ On 8 May 2019, the House Financial Services Committee adopted H.R. 2515, entitled Whistleblower Protection Reform Act of 2019. ${ }^{12}$ H.R. 2515 amended section 922 of the Dodd-Frank Act and extended the statutory protection against retaliation to whistleblower employees who report wrongdoing using internal channels within their employer. The revised Dodd-Frank Anti-Retaliation Act extended the scope of entities to employees who only report misconduct to their employers bypassing the SEC. In the first years after introducing the SOX Act, the effectiveness of the provisions protecting whistleblower employees who were dismissed from their jobs was at a relatively low level, i.e., 3.6\%. Richard. Moberly identified several reasons for this state of affairs (Moberly 2007, p. 32): fair dismissal

8 https://www.congress.gov/bill/111th-congress/house-bill/1/text (access: 27 October 2020).

9 https://www.supremecourt.gov/opinions/05pdf/04-473.pdf (access: 27 October 2020): “Two inquiries guide interpretation of the constitutional protections accorded public employee speech. The first requires determining whether the employee spoke as a citizen on a matter of public concern. See Pickering, supra, at 568. If the answer is no, the employee has no First Amendment cause of action based on the employer' s reaction to the speech. See Connick, supra, at 147. If the answer is yes, the possibility of a First Amendment claim arises. The question becomes whether the government employer had an adequate justification for treating the employee differently from any other member of the general public.

10 Pub. L No. 111-203, 124 Stat 1376 (2010).

11 https://www.phillipsandcohen.com/sec-whistleblower-provisions/ (access: 27 October 2020).

12 https://financialservices.house.gov/uploadedfiles/bills-116hr2515ih-whistledef.pdf (access: 27 October 2020). 
is not limited to whistleblowers; it is broader in scope and includes workers who have been made redundant for justifiable reasons.

1. A significant number of employers did not fall within the scope of the SOX regulations.

2. A frequent reason for employees failing was the lack of timely claims.

3. Moberly stated that workers were often unable to provide sufficient evidence to prove that the signaling was the immediate reason for dismissal.

In turn, David Oppenheimer (2003, pp. 513-533), the law improved the proportion of cases won by employees-whistleblower over the rest. Oppenheimer stated that whistleblowers were more likely to win lawsuits for unfair dismissal due to reporting irregularities.

At this point, it will be justified to present a few conclusions based on which de lege ferenda conclusions will be formulated. First, current whistleblower US laws are based on financial claims, which are intended not only to encourage potential whistleblowers to submit reports but principally to protect whistleblowers against unjustified dismissal, harassment, or discrimination. Rewarding whistleblowers will minimize the consequences of losing a job or suffering other damages that whistleblowers often face. Modern whistleblower laws set minimum and maximum levels of rewards. Guaranteed minimum rewards, which often amount to millions of dollars, are essential to persuade otherwise skeptical potential whistleblowers to act. American laws such as The Foreign Corrupt Practices Act, The Securities Exchange Act, The Commodity Exchange Act, The Internal Revenue Code (they will not be analyzed in this article) permit to reward a whistleblower who is not a US citizen but has provided sufficiently important information that has contributed to the apprehension of fraud. ${ }^{13}$ Second, both the FCA and the SOX Act specified a whistleblower employee (an employee with a traditional employment relationship) who was retaliated by the employer for reporting misconduct. The provisions of the acts, which can be called specific concerning the standard employee protection provisions, increase the protection of whistleblowers. The FCA's reimbursement measures are reinstatement, twice the amount of any outstanding wages, arrears interest, and compensation for any specific damages incurred due to the retaliation, including court costs and attorney fees. The SOX Act stipulates that an employee who suffered retaliation only had to prove that their signaling was a factor contributing to, for example, dismissal. The reporting does not have to be an independent cause of follow-up on the whistleblower, it is enough that it is an additional criterion for the whistleblower to be protected by the provisions of the SOX Act.

13 See https://www.mondaq.com/unitedstates/whistleblowing/889468/the-rise-of-internationalwhistleblowers-qui-tam-rewards-for-non-us-citizens (access: 27 October 2020). 


\section{European Union Legislative}

Whistleblowers are usually employees of a given organization and they are sometimes exposed to direct attack not only inside a given institution, but also from outside its borders. A whistleblower can also be a non-employee of an organization that the whistleblower knows to be doing something improper. For example, a whistleblower may become aware of a person or an entity, such as a financial institution, that is or has committed corruption or fraud. Some countries with a long tradition of whistleblowing provide whistleblower protection by providing them with channels through which employees and jobseekers may disclose confidential information (e.g., United States, Australia). Currently, whistleblower protection is in the process of implementing a single European legal framework, which will protect whistleblowers under European law (Near, Miceli 1985, pp. 1-16).

Starting from 17 December 2019, Member States have two years to implement in national legal systems regulations providing, inter alia, new whistleblower protection institutions, which are primarily designed to provide legal protection to whistleblowers. As shown by the latest data from 21 out of 27 countries $^{14}$ The European Union has started the process of implementing the directive, although, like Germany, for example, it has already encountered resistance from various circles. According to Transparency International, the European Union agrees:

We have 18 months to ensure that the necessary whistleblower legal protection, which we have worked so hard at EU level, really works in practice at national level. These are the same months that Europe will ease restrictions on COVID-19. More whistleblowers will tell us where and how existing weaknesses in our systems have been broken in order to move the necessary public funding away from those who need it most. The EU whistleblower rate will help us request the change we need across Europe to protect whistleblowers who help us protect the public interest. ${ }^{15}$

Current European legislation on whistleblower protection is fragmented and its application varies widely across European Union Member States, with countries like the UK adopting a comprehensive regulatory framework, ${ }^{16}$ while others, such as Italy, are slowly widening the scope (Kobroń 2013, pp. 296-302). In some cases, for example in Poland, protection is based on the provisions of the labor law, which are not of great importance in the aspect of whistleblower protection (Huseynova, Piperigos 2018, pp. 1-6). Current European Union legislation on whistleblower protection is fragmented and its application varies considerably between European Union Member States. ${ }^{17}$ 2021).

${ }^{14}$ See https://euwhistleblowingmeter.polimeter.org/\#promises (excluding Poland) (access: 10 April

15 https://whistleblowingnetwork.org/Our-Work/Spotlight/Stories/FINAL-WIN-EU-Whistleblowing-Meter-Press-Release-22.aspx (access: 27 October 2020).

$16 \mathrm{http} / / /$ www.brownrudnick.com/alert/eu-whistleblowing-directive/ (access: 27 October 2020).

17 European Parliament legislative resolution of 16 April 2019 on the proposal for a directive of the European Parliament and of the Council on the protection of persons reporting on breaches of Union 
The need to regulate whistleblowing at the European Union level is enormous. It is worth making a conclusion at this point that, in my opinion, the United States is probably the leading innovator when it comes to reporting whistleblowing regulations, that is the United States, where the first whistleblower protection regulations appeared in the $19^{\text {th }}$ century (Kobron'-Gąsiorowska 2018, pp. 129-142). Therefore, it is imperative to develop a dedicated EU-wide whistleblower protection legislation applicable to both the public and private sectors, albeit with a predominance for the public sector.

European legislation currently protects informants to a minimal extent. This protection is fragmented or absent (Huseynova, Piperigos 2018, p. 2). The Directive on the protection of persons reporting on breaches of European Union law shows once again that whistleblowers who disclose crimes committed in both the private and public sectors risk not only losing their jobs, but also their professional careers and, in some cases, suffer from severe and prolonged financial, health, image, and social consequences. The Directive is the European Commission's response, which has been repeatedly called upon to intervene, promoting the establishment of common minimum standards of protection in the EU, the level of compliance with the case-law of the European Court of Human Rights on freedom of expression (European Court of Human Rights, Guja v. Moldova, Application No. 14277/04 of 12 February 2008, pp. 1-29, in particular para 97, p. 27). It is often the case that those who choose to report whistleblowing turn to the media first, which plays a crucial role in protecting the whistleblower's reputation. ${ }^{18}$

The proposal for a Directive on the protection of persons reporting on breaches of Union law published on 23 April 2018 by the European Commission was the first comprehensive attempt to create an institution aimed at harmonizing the Member States' legislation in the field of whistleblower protection. As already mentioned, the current level of protection across the Union does not adequately consider the constraints often faced by those who choose to report abuse by publicly disclosing the information obtained to the media (the competent authorities designated both at national and European Union level could be law enforcement departments, ombudsmen, anti-corruption authorities, surveillance bodies or even trade unions).

Finally, on 16 April 2019, the European Parliament adopted the proposal for a Directive on whistleblower protection at first reading by an overwhelming majority. The Directive aims to improve the enforcement of Union law and policies in specific areas by establishing common minimum standards to protect whistleblowers. Protection is to be achieved primarily through their broad definition of whistleblowers, including those who, due to their work-related activities, both in the public and private sectors, have

law (\{COM(2018) 0218\}, C8-0159/2018, 2018/0106(COD)); https://www.europarl.europa.eu/RegData/seance_pleniere/textes_adoptes/provisoire/2019/04-16/0366/P8_TA-PROV(2019)0366_PL.pdf (access: 27 October 2020).

${ }^{18}$ In Poland (March 2020), a nurse was fired, who publicly signaled hard working conditions in the hospital during the pandemic, for which she was dismissed from her job. See: https://forsal.pl/artykuly/1463865,sygnalisci-z-zamknietymi-ustami-lekarze-informujacy-o-nieprawidlowosciach-dostaja-zakaz-rozmow.html (access: 27 October 2020). 
privileged access to information on breaches that may cause serious harm to the public interest. Besides, by providing precise and confidential channels or reporting, both internal and external (although internal reporting will be preferred), the whistleblower is to have a high level of protection against any form of retaliation (direct or indirect). The Directive "establishes common minimum standards of protection for persons reporting illegal activities or abuses of law." The text of the Directive is divided into five chapters.

Chapter I contains Art. 1-3 that define the material and personal scope, introducing the definitions of the most important concepts related to whistleblowing. Article 1 identifies the areas of European Union competence in which the Directive applies, based on the considerations in the impact assessment: I. Public procurement; II. Financial services, prevention of money laundering and terrorist financing; III. Product safety and compliance; IV. Transport safety; V. Environmental protection; VI. Nuclear safety; VII. Food and Feed Safety, Animal Health and Welfare; VIII. Public health; IX. Consumer protection; X. Protection of privacy and personal data, and security of network and information systems (Kobroń-Gąsiorowska 2018, pp. 129-142; 2019, pp. 333-343). However, the Directive encourages the extension of its scope to other areas as well. Article 2 specifies the personal scope of application of the Directive, i.e., persons who are considered eligible for protection in the event of retaliation. In line with the aforementioned international bodies' recommendations and guidelines, the personal scope covers various categories of employees from both the public and private sectors who could obtain information related to breaches of European Union law in their workplace. Therefore, protection should be provided to ordinary workers and self-employed workers, shareholders and managers, and unpaid workers such as volunteers or trainees, contractors and subcontractors, suppliers, and ultimately job applicants $(\{\operatorname{COM}(2018) 218 \mathrm{final}\}$, Proposal for a Directive on the protection of persons reporting on breaches of Union law and Explanatory Memorandum, p. 10). Article 5 specifically outlines what procedures organizations are expected to adopt at the different stages of the post-reporting whistleblowing process:

- Receive a report through internal and secure channels (Art. 5, p. 21).

- Provide timely feedback to the whistleblower.

- Provide necessary information and guidance to employees on the possibilities of external reporting mechanisms.

Law sections 6-12 set out the external reporting procedure. Article 6 describes the elements that qualify a person as a whistleblower. Whistleblowers shall be eligible for protection under the Directive provided that they had reasonable grounds to believe that the information on breaches reported was accurate at the time of reporting and that such information falls within the scope of this Directive, and internal reporting first unless that procedure was found to be insufficient by external reporting. (Explanatory Memorandum, p. 11). Article 8 specifies that small and micro entities are exempt from the obligation to establish and operate internal reporting mechanisms in both the public and private sectors ( $\{\mathrm{COM}(2018) 218$ final $\}$, Proposal for a Directive on the protection of persons reporting on breaches of Union law and Explanatory Memorandum, 
p. 11). Regrettably, this obligation will only apply to organizations employing more than 50 employees, which should be accepted with criticism. Articles 9-10 set out the required operations to be performed. Articles 11 and 12 set out the Member States' responsibilities in establishing independent and effective external reporting channels and in the following investigative, follow-up and feedback operations to the reporting person, guided by the principles of confidentiality and independence. It specifies the minimum standards applicable to such channels and procedures $(\{\operatorname{COM}(2018) 218$ final $\}$, Proposal for a Directive on the protection of persons reporting on breaches of Union law and Explanatory Memorandum, p. 12). Articles 13-18 are the central part of the Directive as they contain the main provisions relating to measures to protect against retaliation those who report irregularities. The whistleblower will be protected but must have reasonable grounds to believe its submission is accurate at the time of filing. The Directive has adopted a model of a multi-tiered irregularity reporting method, in which the whistleblower is required first to make an internal report and then may use external channels as a second option if the first fails, while only as a last resort may disclose information to the media or the general public (Art. 13, p. 12). As pointed out by the Commission, this requirement is necessary to ensure that information reaches those who can contribute to the early and effective resolution of threats to the public interest and prevent unjustified reputational damage due to public disclosure (Explanatory Memorandum, p. 13). On the one hand, one can risk the validity of such a request, intended to protect the employer. On the other hand, it should be indicated that an employer may not want to cooperate with a whistleblower for various reasons, e.g., financial. Article 19 provides for the creation of non-retaliatory whistleblower laws that prohibit retaliation against those who attempt to retaliate and those who support them. Interestingly, the provision lists examples of retaliation forms, most of which relate to typical employee rights, e.g., suspension, forced unpaid leave, dismissal, demotion or suspension of promotion, workplace change, and reduction of salary, change of working hours, and suspension of training. Only the early termination or termination of the goods or services contract and the revocation of the license or authorization are nonlaborious (Art. 19, p. 13). The Directive aims to create a solid European framework for the protection of whistleblowers who have reasonable information about breaches of European Union law, but the Directive does not cover anyone who has legitimate information about irregularities in the workplace. It is accurate that the need to ensure a safe working environment in which employees and other employed persons can speak freely against violations and offenses has been indicated, it will strengthen the protection and promotion of rights and freedoms such as freedom of expression and information, protection and respect for privacy and personal data, and the right to decent working conditions (Guja v. Moldova).

The protection of the European Union's financial interests is the main area that the European Union wants to strengthen. Lack of enforcement of the financial rules reduces revenues or the budget as a whole, which in turn leads to inefficient public service 
delivery and distorts public investment and growth and lower economic performance across the European Union.

The European Union is committed to fighting fraud at national levels of individual countries, where fraud, corruption, and other undue measures constitute infringements that can also seriously affect the financial interests of the Union. However, it should not be forgotten that the Directive's purpose is to protect the whistleblower first. One of them is the substantive scope of the proposed Directive, which, although it tries to cover many different areas of European Union law, leaves the possibility for the Member States to extend the scope further (Paton et al. 2013, p. 4), which may result in the entire legitimacy of whistleblowers.

The European Union exempts some public and private entities from introducing internal reporting structures and allowing their expansion. Finally, the Directive does not deal with whistleblower financial rewards, where the US authorities take a different approach and are worth examining from a European perspective. While the Commission considered the issue itself due to the expected costs to be borne by the public and private sectors, these were ultimately not addressed in the texts of the Directive. A positive aspect is the introduction of transitional periods for employers with a minimum of 50 employees, for whom the obligation to introduce reporting procedures was postponed until 17 December 2023. ${ }^{19}$

\section{Summary and de lege ferenda remarks}

There are no uncertainties that the Anglo-Saxon legal system has advanced an efficient whistleblower protection system over the years and is now a pioneer in this matter. The US has a well-developed whistleblowing legal system, and the evidence presented in this article suggests that it has had a positive impact on whistleblowing. In Europe, intensified work has also been undertaken to create uniform rules for protecting the European Unions's public interest and informants who will report these irregularities in the Member States. After analyzing the provisions of the Whistleblower Protection Directive, the Directive defines the existence of a general "Community" or "European interest," which proves the coherence of European Union countries in the field of whistleblower protection. The Directive itself must be implemented in practical terms in the Member States, and its task is to harmonize legal provisions. After analyzing the US law and practice, we can reach the following conclusions.

First, whistleblowing laws in the United States have developed over the years, and their current shape is the result of the evolution of US legislation. Second, these provisions are based on the strong relationship of whistleblower protection with financial rewards in both the FCA and SOX. The financial reward is not only a compensation

19 European Commission, Impact Assessment (n. 11) 36, where the European Commission states that: "Member States retain the possibility to apply further measures to facilitate or encourage whistleblowing, which go beyond the core standards promoted by the ECtHR/CoE, such as rewards." 
role but also an incentive for potential whistleblowers. Third, whistleblowers have not been limited by the obligation to report irregularities first through internal channels. Fourth, the scope of the Directive covers not only employees who are in a traditional employment relationship. There are no specific provisions that would define the scope of protection, e.g., for principals. Such people will not be reinstated, or they will not be paid compensation for harassment at work that they experienced while performing the assignment. Finally, we should consider whether we will treat the reporting included in the Directive as a right or a moral obligation. Nevertheless, the Directive requires no clear incentives for reporting by prospective whistleblowers. I apply the presented doubts as de lege ferenda comments. The effectiveness of the Directive's provisions will positively be assessed to protect the provisions and the incentives to report.

\section{References}

Dyck A., Morse A., Zingales L. (2010) Who Blows the Whistle on Corporate Fraud?, "Journal of Finance," Vol. 65, Issue 6.

Alford C.F. (2001) Whistleblowers: Broken Lives and Organizational Power, https://whistleblowersblog.org/2018/03/articles/whistleblower-news/corporate-whistleblowers/inside-themind-of-a-whistleblower/ (access: 12 October 2020).

Bhagat S., Bolton B. (2009) Sarbanes-Oxley, Governance and performance, Working Paper, University of Colorado at Boulder.

Boatright J. (2000) Ethics and the Conduct of Business, $3^{\text {rd }}$ Ed., Upper Saddle River.

Calvert L. (1998) The Qui Tam Provision of the False Claims Act: Congressional Missile or a Net Full of Holes?, "The Annual Survey of American Law."

Ching-Pu Ch., Tsung Lai Ch. (2014) To Blow or not to Blow the Whistle: The effects of potential harm, social pressure and organisational commitment on whistleblowing intention and behaviour, „Business Ethics: A European review,” Vol. 23, Issue 3.

Farrell D., Petersen J.C. (1982) Patterns of Political Behavior in Organizations, "Academy of Management Review," Vol. 7.

Hirschman A.O. (1970) Exit, Voice, and Loyalty: Responses to Decline in Firms, Organizations and States, Cambridge (Mass.).

Huseynova D., Piperigos K. (2018) Justice for Justice: Protecting Whistleblowers in the EU. Protection of Whistleblowers: The Why and the How, http://transparency.eu/wp-content/ uploads/2018/04/WB_Transparency-Group-CoE-17-18.pdf (access: 12 August 2020).

Johnson R. (2003) Whistle-Blowing: When It Works-And Why, Boulder.

Jubb P.B. (1999) Whistleblowing: A Restrictive Definition and Interpretation, "Journal of Business Ethics," Vol. 21.

King G. III (1999) The Implications of an Organization's Structure on Whistleblowing, "Journal of Business Ethics," Vol. 20(4).

Kobroń Ł. (2013) Whistleblower. Strażnik wartości czy donosiciel?, “Palestra,” nr 11-12. 
Kobroń Ł. (2015) Czy Polskę czeka era etycznych donosów?, "Zeszyty Naukowe Towarzystwa Doktorantów UJ. Nauki Społeczne," t. 10.

Kobroń-Gąsiorowska Ł. (2018) Whistleblower w prawie europejskim. Ochrona whistleblowera czy informacji, "Roczniki Administracji i Prawa," t. 2.

Kobroń-Gąsiorowska Ł. (2019) Interes Publiczny jako element podstawowy funkcji ochronnej prawa pracy - w kontekście ochrony sygnalistów, "Roczniki Administracji i Prawa," t. 2.

Kohn S. (2006) What Price Free Speech? Whistleblowers and the Garcetti v. Ceballos Decision, National Whistleblowers Centre, https://www.whistleblowers.org/wp-content/uploads/2018/10/ ceballos.final_testimony.pdf (access: 12 October 2020).

Lacayo R., Ripley A. (2002) Persons of the Year, http://content.time.com/time/magazine/ article/0,9171,1003998,00.html (access: 12 October 2020).

Liszcz T. (2005) Ogólna charakterystyka prawa pracy [in:] R. Borek-Buchajczuk (red.), Zarys prawa pracy, Lublin.

Moberly R.E. (2007) SOX and Whistleblowing: The Concerns, College of Law, "Faculty Publications," Vol. 32.

Moberly R.E. (2012) Sarbanes-Oxley's Whistleblower Provisions: Ten Years Later, "South Carolina Law Review," Vol. 64.

Nader R., Petkas P.J., Blackwell K. (eds.) (1972) Whistle Blowing: The Report of the Conference on Professional Responsibility, New York.

Near J.P., Rehg M.Y., Scotter J.R. Van, Miceli M.P. (2009) Does Type of Wrongdoing Affect the Whistle-Blowing Process?, "Business Ethics Quarterly," Vol. 14(2).

Near J.P., Miceli M.P. (1985) Organizational Dissidence: The Case of Whistle-Blowing, "Journal of Business Ethics," Vol. 4.

Near J.P., Miceli M.P. (1992) Blowing the Whistle: The Organizational and Legal Implications for Companies and Employees, New York.

Near J.P., Rehg M.T., Scotter Van J., Miceli M.P. (2004) Does Type of Wrongdoing Affect the Whistle-Blowing Process, „Business Ethics Quarterly,” Vol. 14, No. 2.

Near J.P., Miceli M.P., Dworkin T.M. (2009) A Word to the Wise: How Managers and Policy-Makers Can Encourage Employees to Report Wrongdoing, "Journal of Business Ethics," Vol. 86(3).

North G., Buckley R. (2012) The Dodd-Frank Wall Street Reform and Consumer Protection Act: Unresolved Issues of Regulatory Culture and Mindset, "Melbourne University Law Review," Vol. 35(2).

Omzigt P. (2009) The Protection of "Whistle-Blowers," https://assembly.coe.int/nw/xml/XRef/ Xref-XML2HTML-en.asp?fileid=12302\&lang=en (access: 12 August 2020).

Oppenheimer D.B. (2003) Verdicts Matter: An Empirical Study of California Employment Discrimination and Wrongful Discharge Jury Verdicts Reveals Low Success Rates for Women and Minorities, https://heinonline.org/HOL/LandingPage?handle=hein.journals/ davlr37\&div $=25 \&$ id $=$ \&page $=($ access: 12 August 2020).

Paton W.O., Ferguson R., Bingham Ch., Casadonte D.J. (2013) Whistleblowing in Higher Education, https://ttu-ir.tdl.org/bitstream/handle/2346/50651/Bard_Jennifer_Diss.pdf?sequence=1 (access: 12 August 2020).

Sobczyk A. (2014) Różnicowanie praw (ochrony) zatrudnionych - wybrane kryteria i ich ocena [in:] M. Bosak (red.), Funkcja ochronna prawa pracy a wyzwania współczesności, Warszawa.

Vaughn R.G. (2005) America's First Comprehensive Statute Protecting Corporate Whistleblowers, “Administrative Law Review," Vol. 57, No. 1. 
Wolfe S., Worth. M., Dreyfus S., Brown A.J. (2014) Whistleblower Protection Laws in G20 Countries: Priorities for Action, https://webarchive.nla.gov.au/awa/20140908101050/http:// pandora.nla.gov.au/pan/148392/20140917-0713/blueprintforfreespeech.net/wp-content/ uploads/2014/09/Whistleblower-Protection-Laws-in-G20-Countries-Priorities-for-Action. pdf (access: 20 October 2020).

\section{Court sentences}

Judgment of the Supreme Court of 15 November 2001, II UKN 620/00, OSNP 2003, No. 15, item 367.

Judgment of the Supreme Court of 3 March 1975, I PR 16/75, Lex Polonica 318105.

European Court of Human Rights, Guja v. Moldova, Application No. 14277/04 of 12 February 2008.

Garcetti v. Ceballos, 547 U.S. 410 (2006).

United States ex rel. Marcus v. Hess, 317 U.S. 537, 541-42, 1943.

United States v. Griswold, 24 F. 361, 366, 1885.

Welch v. Cardinal Bankshares Corp., 407 F. Supp. 2d 773 (W.D. Va. 2006).

\section{Legal acts}

Directive (EU) 2019/1937 of the European Parliament and of the Council of 23 October 2019 on the protection of persons who report breaches of Union law.

Dodd-Frank Wall Street Reform and Consumer Protection Act, Pub. L No. 111-203.

European Parliament legislative resolution of 16 April 2019 on the proposal for a directive of the European Parliament and of the Council on the protection of persons reporting on breaches of Union law, \{COM(2018) 0218\}, C8-0159/2018, 2018/0106(COD).

False Claims Amendments Act (1986). Pub. L No. 99-562, 100 Stat. 3153, codified as amended at 31 U.S.C. $\$ \$ 3729-3733$.

Sarbanes-Oxley Act (2002). Pub. L No. 107-204, 116 Stat. 745. 